\title{
Heterocyclyl linked anilines and benzaldehydes as precursors for biologically significant new chemical entities
}

\author{
RAMAN K VERMA $^{\mathrm{a}, *}$, VIJAY KUMAR ${ }^{\mathrm{a}}$, PRITHWISH GHOSH ${ }^{\mathrm{a}}$ and LALIT K WADHWA ${ }^{\mathrm{b}}$ \\ a Synthetic Organic and Medicinal Chemistry Laboratory, Department of Chemistry, Punjabi University, \\ Patiala 147 002, India \\ bInd-Swift Laboratories Limited (Research and Development Centre), Plot No. E-5, Industrial Area, Phase-2, \\ SAS Nagar, Mohali 160 055, India \\ e-mail: raman_verma58@yahoo.com
}

MS received 28 November 2011; revised 25 February 2012; accepted 8 March 2012

\begin{abstract}
Benzylidene and benzyl thiazolidinediones, oxazolidinediones, isoxazolidinediones and their acyclic analogs like alpha alkylthio/alkoxy phenylpropanoic acids, beta-keto esters and tyrosine-based compounds possess broad therapeutic potential in general and as Peroxisome Proliferator Activated Receptors (PPARs) agonists in particular in the management of hyperglycemia and hyperlipidaemia for the treatment of Type 2 Diabetes (T2D). We have synthesised and characterized some novel and suitably substituted heterocyclyl linked benzaldehydes and anilines, which can be easily and very readily derivatized to all the above mentioned classes to generate new chemical entities of broader biological significance. Synthesis of their benzylidene thiazolidinedione and diethyl malonate and also benzyl diethyl malonate and alpha-bromoesters derivatives is reported in some of the cases in the present work.
\end{abstract}

Keywords. Benzimidazole; indole; acridone; benzaldehyde; aniline.

\section{Introduction}

It is well-documented in the literature that benzimidazole, indole and acridone scaffolds are important structural core in medicinal chemistry because their derivatives exhibit illustrious biological and pharmacological activities. The synthesis of benzimidazole derivatives has gained importance during recent years because of their broad spectrum of activities as antiviral, ${ }^{1}$ antitumour, ${ }^{2}$ antioxidant, ${ }^{3}$ anticoagulant, ${ }^{4}$ antihypertensive $^{5}$ and antiparasitic agents. ${ }^{6}$

Indole nucleus is another heterocyclic pharmacophoric component of immense medicinal significance. Suitably substituted or fused indole ring containing compounds demonstrate antiproliferative activity in many types of human cancer cells, ${ }^{7}$ agonism to cannabinoid receptors, ${ }^{8}$ antitumour activity, ${ }^{9}$ free radical scavenging activity, ${ }^{10,11}$ anti-inflammatory activity. ${ }^{11}$ Similarly, acridone nucleus is also indispensible

*For correspondence in drug discovery research. The compounds containing acridone structural unit may act potentially as antiherpesvirus agents, ${ }^{12}$ antitumour agents, ${ }^{13}$ NS3 helicase inhibitor (that inhibits hepatitis C virus replication), ${ }^{14}$ antimalarial agents. ${ }^{15}$

Aldehyde and amino, the two important functional groups, are of versatile utility in the field of organic synthesis. A medicinally significant library of numerous compounds, which may prove to be potent pharmacological agents, can be prepared starting from substituted benzaldehydes and aminobenzenes. Pharmacologically active 2,4-thiazolidinediones, ${ }^{16}$ oxazolidinediones, ${ }^{17}$ isoxazolidine-3,5-dione, ${ }^{18}$ 1,3-dicarbonyls, ${ }^{18}$ (1,3-diacids, 1,3-diesters, 1,3-diamides), ${ }^{18}$ and $\alpha$-alkoxy carboxylic acids ${ }^{19,20}$ (figure 1) have been prepared from variously heterocyclyl linked benzaldehydes. Similarly, there are reports of pharmacologically active 2,4-thiazolidinediones ${ }^{21,22}$ and thiazolidinone derivatives ${ }^{23}$ prepared from heterocycle linked aminobenzenes. The $\alpha$-bromopropanoic acid ester derivative prepared from substituted aminobenzene leads to $\alpha$-alkylthiocarboxylic acids ${ }^{19}$ and Tyrosine derivatives ${ }^{24}$ are of immense importance for the treatment of T2D. Reviewing the synthetic application of the discussed, our work is projected upon three heterocycles and the two functional groups mentioned. 


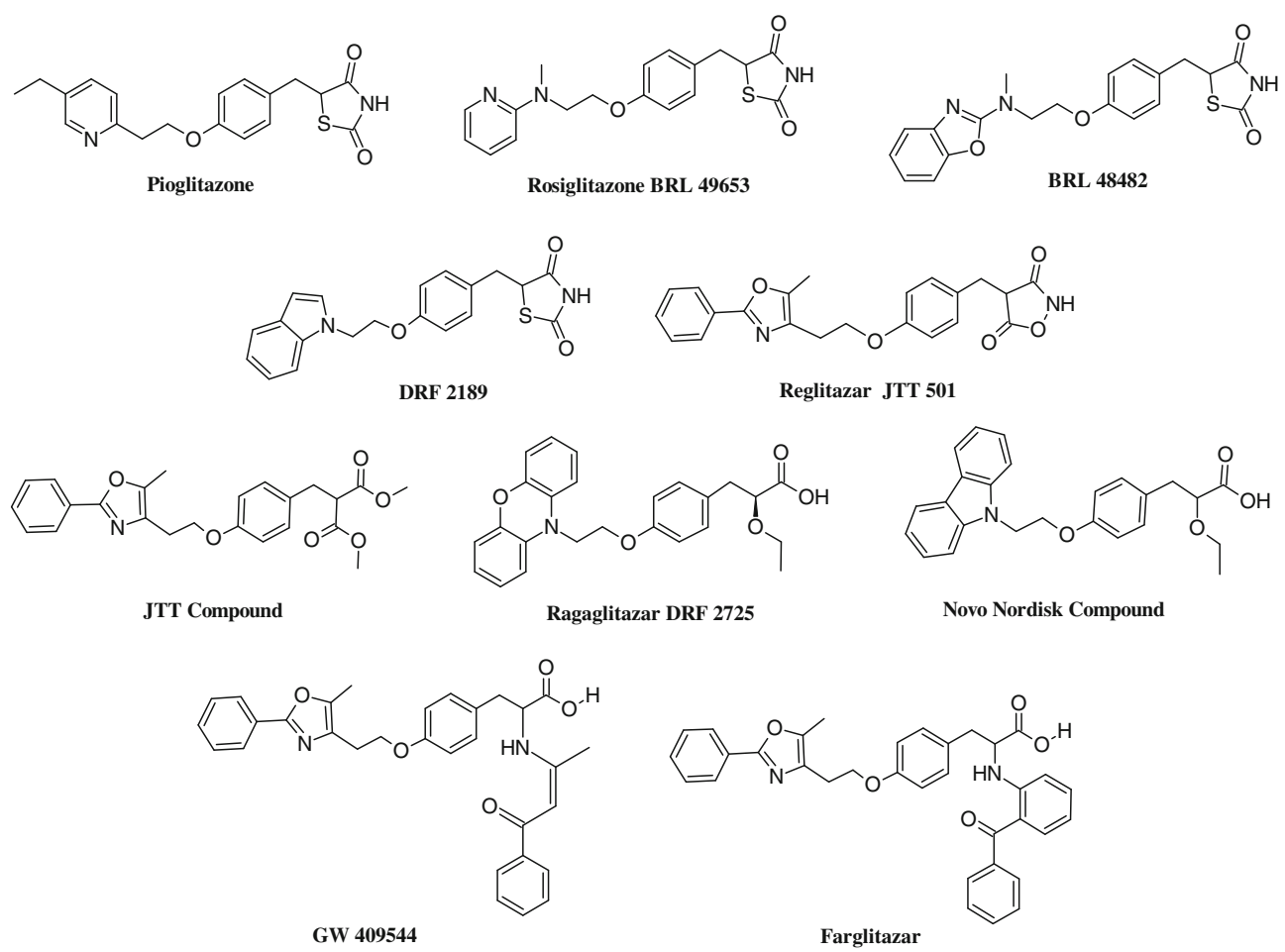

Figure 1. PPAR activating molecules.

\section{Experimental}

\subsection{Materials and methods}

All the chemicals used in the present work were purchased from SD Fine Chemical and Aldrich Chemical Company. The melting/boiling points reported here were recorded using an open conc. sulphuric acid bath and are uncorrected. The Infrared and ${ }^{1} \mathrm{H}$ NMR spectra of these compounds were recorded on Perkin-Elmer Spectrum RX FTIR Spectrophotometer and AC400F, $400 \mathrm{MHz}$ Bruker spectrometer at RSIC, Panjab University, Chandigarh. LCMS of these compounds were recorded on LCMS LCQ Finnigan Matt (APCI +ve mode) at Central Instrumentation Lab, NIPER, SAS Nagar, Mohali, Punjab. GCMS and Elemental analysis of these compounds were carried out on Shimadzu GCMS-QP2010 Plus and VarioMICRO VI Elemental Analyzer respectively at Instrumental Laboratory, Department of Chemistry, Punjabi University, Patiala.

\subsection{General procedure for the synthesis of heterocyclyl linked anilines 3, 7 and 11}

To (3.1 mmol) of the respective nitro compound $(2,6,10)$ placed in a Parr bottle with $10 \%$ Palladium on charcoal $(300 \mathrm{mg})$ and methanol/dioxane $(150 \mathrm{ml})$, and the mixture was hydrogenated at $20 \mathrm{psi}$ for $2 \mathrm{~h}$. The catalyst was filtered through diatomaceous earth/celite and the filtrate was evaporated under reduced pressure to give a residue which upon trituration with hexane or upon column chromatography (hexane/EtOAc, 1:5) gave the desired compound as a solid.

2.2a 4-[(1-Methyl-1H-benzimidazol-2-yl)methoxy]aniline (compound 3, scheme 1): Yield: 75\%, mp: $138-140^{\circ} \mathrm{C}$; FTIR (KBr): 3447, 3317, 2942, 2840, 1512, 1480, 1446, 1364, 1246, 1035, 831, 747. $\mathrm{cm}^{-1} ;{ }^{1} \mathrm{H}$ NMR $\left(\mathrm{CDCl}_{3}\right) \delta: 7.76(\mathrm{~d}, 2 \mathrm{H}), 7.36-$ $7.27(\mathrm{~m}, 3 \mathrm{H}), 6.89(\mathrm{~d}, \mathrm{~J}=6.56 \mathrm{~Hz}, 1 \mathrm{H}), 6.63(\mathrm{~d}, \mathrm{~J}=$ $6.64 \mathrm{~Hz}, 2 \mathrm{H}), 5.30$ (s, 2H), 3.88 (s,3H), 2.78 (br.s, 2H); LCMS m/z (254) $[\mathrm{M}+1]^{+}$; Anal. Calcd for $\mathrm{C}_{15} \mathrm{H}_{15} \mathrm{~N}_{3} \mathrm{O}$ : C, 71.13; H, 5.97; N, 16.59. Found: C, 71.75; H, 5.68; N, 16.82 .

$2.2 \mathrm{~b}$ 4-[(1-Methyl-1H-indol-2-yl)methoxy]aniline (compound 7, scheme 2): Yield: 50\%, mp: 141$143^{\circ} \mathrm{C}$; FTIR (KBr): 3500-3200, 2923, 2840, 1656, 1593, 1511, 1468, 1380, 1232, 1010,832, $751 \mathrm{~cm}^{-1}$; ${ }^{1} \mathrm{H}$ NMR $\left(\mathrm{CDCl}_{3}\right) \delta: 7.59(\mathrm{~d}, 1 \mathrm{H}), 7.33-7.31(\mathrm{~m}, 1 \mathrm{H})$, 7.25-7.21 (m, 1H), 7.11-7.07 (m, 1H), $6.84(\mathrm{~d}, \mathrm{~J}=$ $8.8 \mathrm{~Hz}, 2 \mathrm{H}), 6.66-6.63(\mathrm{~d}, \mathrm{~J}=8.8 \mathrm{~Hz}, 2 \mathrm{H}), 6.54(\mathrm{~s}, 1 \mathrm{H})$, 5.10 (s, 2H), 3.80 (s, 3H); LCMS m/z (253) $[\mathrm{M}+1]^{+}$; Anal. Calcd for $\mathrm{C}_{16} \mathrm{H}_{16} \mathrm{~N}_{2} \mathrm{O}: \mathrm{C}, 76.16 ; \mathrm{H}, 6.39 ; \mathrm{N}$, 11.10. Found: C, 76.45; H, 6.07; N, 11.44 . 


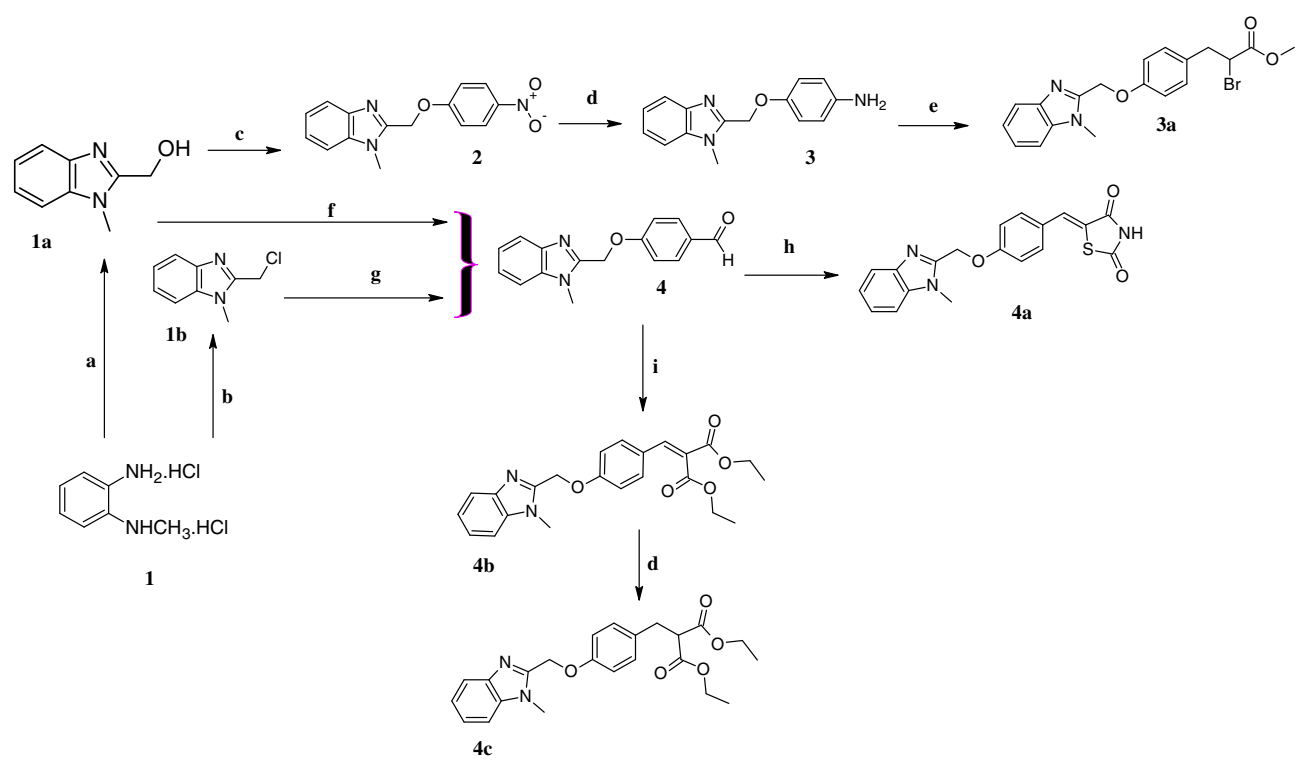

Scheme 1. Synthesis of benzimidazolyl linked compounds. a: Glycolic acid, $\mathrm{H}_{2} \mathrm{O}$, Reflux; b: chloroacetic acid, $\mathrm{H}_{2} \mathrm{O}$, reflux; c: 4-chloronitrobenzene, $\mathrm{NaH}, \mathrm{DMF}$, rt; d: $\mathrm{Pd} / \mathrm{C}-\mathrm{H}_{2}$, methanol, rt; e: methanol, acetone, $\mathrm{HBr}, \mathrm{NaNO}_{2}$, methyl acrylate, $\mathrm{Cu}_{2} \mathrm{O}$; f: 4fluorobenzaldehyde, NaH, DMF, rt; g: 4-hydroxybenzaldehyde, NaH, DMF, rt; h: 2,4thiazolidinedione, piperidinium acetate, toluene, reflux; i: diethyl malonate, piperidinium acetate, toluene, reflux.

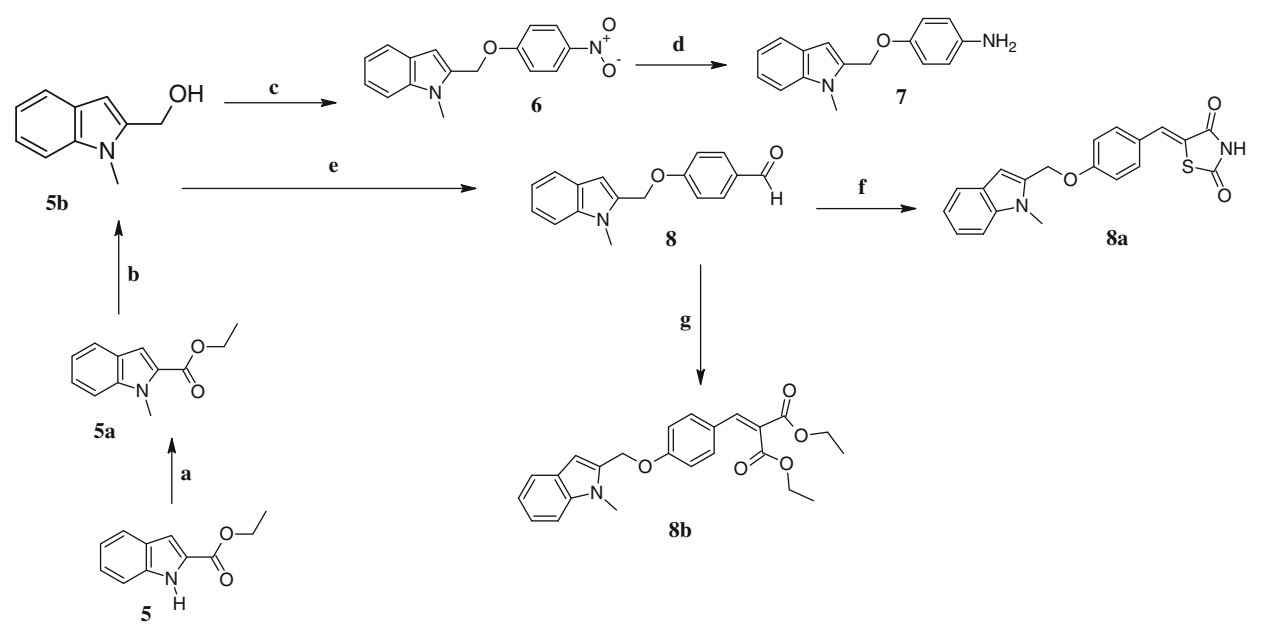

Scheme 2. Synthesis of indolyl linked compounds. a: $\mathrm{CH}_{3} \mathrm{I}, \mathrm{NaH}, \mathrm{DMF}$; b: $\mathrm{LiAlH}_{4}-$ THF; c: 4-chloro nitrobenzene, NaH, DMF, rt; d: Pd/C- $\mathrm{H}_{2}$, methanol; e: 4-fluorobenzaldehyde, $\mathrm{NaH}, \mathrm{DMF}, \mathrm{rt}$; f: 2,4-thiazolidinedione, piperidinium acetate, toluene, reflux; g: piperidinium acetate, toluene, reflux.

2.2c 10-[3-(4-Aminophenoxy)propyl]acridin-9(10H)one (compound 11, scheme 3): Yield: $86 \%$, mp: 151$153^{\circ} \mathrm{C}$; FTIR (KBr): 3335, 3500-3200, 2924, 2840, $1629,1595,1509,1491,1459,1375,820,753 \mathrm{~cm}^{-1}$; ${ }^{1} \mathrm{H}$ NMR $\left(\mathrm{CDCl}_{3}\right) \delta: 8.60-8.57(\mathrm{~m}, 2 \mathrm{H}), 7.71-7.67$ (m, 2H), 7.64-7.62 (d, 2H), 7.31-7.27 (m, 2H), 6.81 $(\mathrm{d}, \mathrm{J}=8.8 \mathrm{~Hz}, 2 \mathrm{H}), 6.68(\mathrm{~d}, \mathrm{~J}=8.8 \mathrm{~Hz}, 2 \mathrm{H}), 4.63$ $(\mathrm{t}, \mathrm{J}=7.5 \mathrm{~Hz}, 2 \mathrm{H}), 4.08(\mathrm{t}, \mathrm{J}=5.3 \mathrm{~Hz}, 2 \mathrm{H}), 3.48$ (br.s, $2 \mathrm{H}$ ), 2.38 (quintet, $\mathrm{J}=2.8 \mathrm{~Hz}, 2 \mathrm{H}) ; \mathrm{LCMS} \mathrm{m} / \mathrm{z}(345$,
100) $[\mathrm{M}+1]^{+}$; Anal. Calcd for $\mathrm{C}_{22} \mathrm{H}_{20} \mathrm{~N}_{2} \mathrm{O}_{2}$ : C, 76.72; H, 5.85; N, 8.13. Found: C, 76.59; H, 5.57; N, 8.29.

\subsection{General procedure for the synthesis of heterocyclyl linked benzaldehydes $\mathbf{4}$ and $\mathbf{8}$}

To a stirred suspension of sodium hydride $(1.4 \mathrm{mmol}$, $60 \% \mathrm{w} / \mathrm{w}$ dispersion) in dry DMF $(20 \mathrm{ml})$ was added 


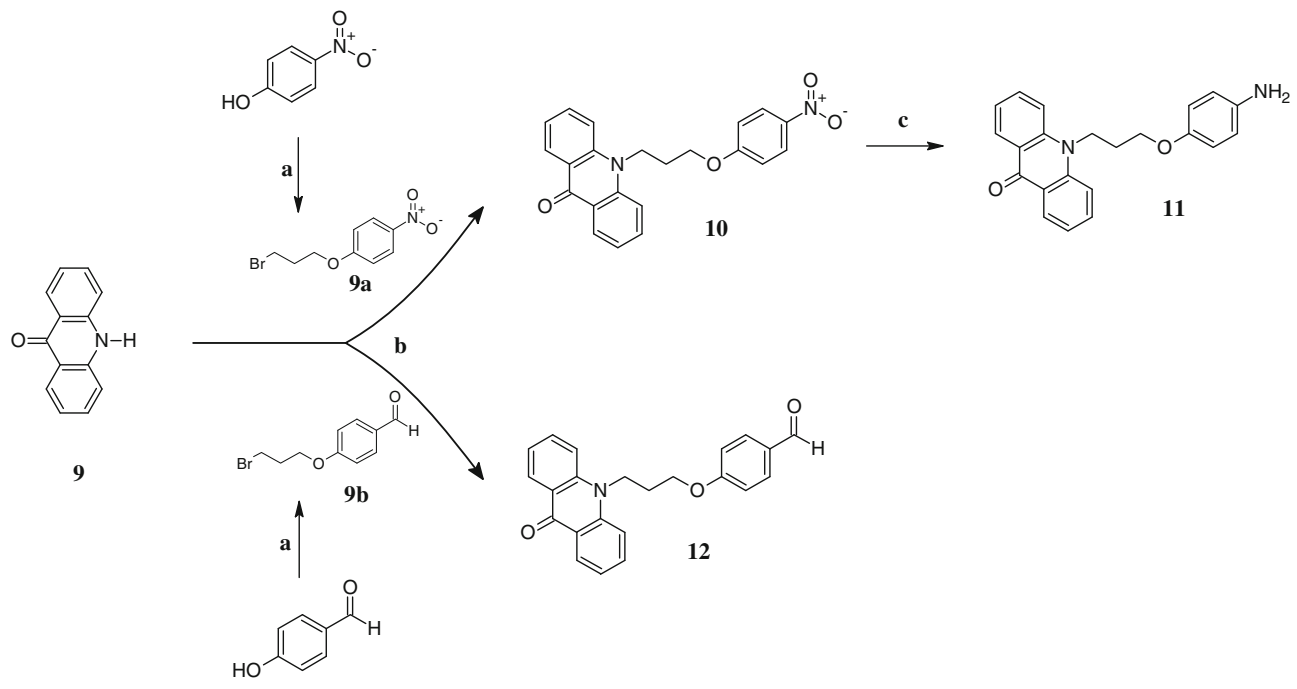

Scheme 3. Synthesis of acridonyl linked compounds. a: 1,3-Dibromopropane, $\mathrm{K}_{2} \mathrm{CO}_{3}$, acetone; b: KOH, DMF (MW); c: Pd/C- $\mathrm{H}_{2}$, methanol.

$(1 \mathrm{a} / 5 \mathrm{~b})(1.2 \mathrm{mmol})$ in dry $\operatorname{DMF}(5 \mathrm{ml})$ at $0^{\circ} \mathrm{C}$, and the mixture was stirred for $30 \mathrm{~min}$ at room temperature $(\mathrm{rt})\left(\mathrm{ca} .30^{\circ} \mathrm{C}\right)$. A solution of 4-fluorobenzaldehyde $(1.3 \mathrm{mmol})$ in dry DMF $(5 \mathrm{ml})$ was added drop-wise over $15 \mathrm{~min}$ at $0^{\circ} \mathrm{C}$, and stirred for $24 \mathrm{~h}$ at rt. The reaction mixture was quenched with water and extracted with EtOAc $(3 \times 30 \mathrm{ml})$. The combined organic extracts were washed with brine, dried over anhydrous $\mathrm{Na}_{2} \mathrm{SO}_{4}$, and concentrated. The residue was chromatographed over silica gel using a mixture of methanol and dichloromethane (1:10).

Compound 4 was also prepared by reacting 2(chloromethyl)-1-methyl-1 $H$ benzimidazole (1b) with 4-hydroxybenzaldehyde in the presence of sodium hydride taken in DMF following similar procedure.

2.3a 4-[(1-Methyl-1H-benzimidazol-2-yl)methoxy]benzaldehyde (compound 4, scheme 1): Yield: 30 and 58.20\%, mp: 120-122 ${ }^{\circ} \mathrm{C}$; FTIR (KBr): 2926, 2823 , 2733, 1697, 1601, 1577,1482, 1430, 1363, 1247,1005, $828,749 \mathrm{~cm}^{-1} ;{ }^{1} \mathrm{H}$ NMR $\left(\mathrm{CDCl}_{3}\right) \delta: 9.88(\mathrm{~s}, 1 \mathrm{H})$, 7.86-7.81 (m, 3H), 7.42-735 (m, 3H), 7.25-7.23 (d, $\mathrm{J}=9.44 \mathrm{~Hz}, 2 \mathrm{H}), 5.52(\mathrm{~s}, 2 \mathrm{H}), 3.91(\mathrm{~s}, 3 \mathrm{H})$; GCMS $\mathrm{m} / \mathrm{z}(\%): 266,25)[\mathrm{M}]^{+}, 145$ (100); Anal. Calcd for $\mathrm{C}_{16} \mathrm{H}_{14} \mathrm{~N}_{2} \mathrm{O}_{2}$ : C, 72.16; H, 5.30; N, 10.52. Found: C, $72.51 ; \mathrm{H}, 5.57 ; \mathrm{N}, 10.19$.

$2.3 \mathrm{~b}$ 4-[(1-Methyl-1H-indol-2-yl)methoxy]benzaldehyde (compound 8, scheme 2): Yield: 30\%, mp: $158-160^{\circ} \mathrm{C}$; FTIR (KBr): 2933, 2823, 2733, 1697, $1598,1506,1468,1380,1244,1160,828,754 \mathrm{~cm}^{-1}$; ${ }^{1} \mathrm{H} \mathrm{NMR}\left(\mathrm{CDCl}_{3}\right) \delta: 9.90(\mathrm{~s}, 1 \mathrm{H}), 7.86(\mathrm{~d}, \mathrm{~J}=8.76 \mathrm{~Hz}$
2H), $7.62(\mathrm{~d}, 1 \mathrm{H}), 7.35-7.33(\mathrm{~m}, 1 \mathrm{H}), 7.28-7.24(\mathrm{~m}$, $1 \mathrm{H}), 7.13(\mathrm{~d}, \mathrm{~J}=8.76 \mathrm{~Hz}, 2 \mathrm{H}), 6.63(\mathrm{~s}, 1 \mathrm{H}), 5.29$ (s, 2H), 3.82 (s, 3H); LCMS m/z (266) [M+1] ${ }^{+}$; Anal. Calcd for $\mathrm{C}_{17} \mathrm{H}_{15} \mathrm{NO}_{2}$ : C, 76.96; H, 5.70; N, 5.28. Found: C, 76.58; H, 5.55; N, 5.60.

2.4 Synthesis of 4-[3-(9-oxoacridin-10(9H)-yl)propoxy]benzaldehyde (compound 12, scheme 3)

To a mixture of acridone (9) $(0.097 \mathrm{~g}, 0.5 \mathrm{mmol})$ in DMF $(15 \mathrm{ml})$ in a beaker, was added 4-(3bromopropoxy)benzaldehyde (9b) $(0.146 \mathrm{~g}, 0.6 \mathrm{mmol})$ and $\mathrm{KOH}(0.200 \mathrm{~g}, 3.6 \mathrm{mmol})$. The mixture was irradiated in a microwave oven for $5 \mathrm{~min}$ at $320 \mathrm{~W}$, and then the reaction mixture was poured into water $(10 \mathrm{ml})$ with stirring. After filtration of the insoluble materials, the filtrate was neutralized ( $\mathrm{pH} 7.0)$ with $2 \mathrm{M}-\mathrm{HCl}$, and extracted with EtOAc $(3 \times 25 \mathrm{ml})$. The organic layers were combined, washed with brine and water, dried over $\mathrm{Na}_{2} \mathrm{SO}_{4}$ and evaporated. The pure product (12) was obtained as a yellow solid $(0.030 \mathrm{~g}, 16.8 \%)$ by column chromatography of the residue using methanoldichloromethane (1:99) mixture as eluent: mp 138$140^{\circ} \mathrm{C}$; FTIR (KBr): 2954, 2880, 1685, 1600, 1496, 1462, 1314, 1258, 1160, 1057, 832, $761 \mathrm{~cm}^{-1} ;{ }^{1} \mathrm{H}$ NMR $\left(\mathrm{CDCl}_{3}\right) \delta: 9.85(\mathrm{~s}, 1 \mathrm{H}), 8.54-8.52(\mathrm{~m}, 2 \mathrm{H}), 7.81(\mathrm{~d}$, $\mathrm{J}=8.76 \mathrm{~Hz}, 2 \mathrm{H}), 7.64-7.62(\mathrm{~m}, 2 \mathrm{H}), 7.60-7.53(\mathrm{~m}$, $2 \mathrm{H}), 7.25-7.21(\mathrm{~m}, 2 \mathrm{H}), 6.98(\mathrm{~d}, \mathrm{~J}=8.76,2 \mathrm{H}), 4.61(\mathrm{t}$, $\mathrm{J}=7.6 \mathrm{~Hz}, 2 \mathrm{H}$ ), $4.15(\mathrm{t}, \mathrm{J}=4.8 \mathrm{~Hz}, 2 \mathrm{H}$ ), 2.40 (quintet, $\mathrm{J}=6.4 \mathrm{~Hz}, 2 \mathrm{H})$; LCMS m/z $(358,100)[\mathrm{M}+1]^{+}$; Anal. Calcd for $\mathrm{C}_{23} \mathrm{H}_{19} \mathrm{NO}_{3}$ : C, 77.29; H, 5.36; N, 3.92. Found: C, 77.61; H, 5.57; N, 28.19. 
2.5 Synthesis of methyl 2-bromo-3-\{4-[(1-methyl-1Hbenzimidazol-2-yl)methoxy]phenyl\} propanoate (compound 3a, scheme 1)

To a slurry of (3) $(1 \mathrm{~g}, 3.9 \mathrm{mmol})$ in methanol $(10 \mathrm{ml})$ and acetone $(10 \mathrm{ml})$, cooled to $-10^{\circ} \mathrm{C}$, was added $48 \%$ aqueous $\mathrm{HBr}(0.83 \mathrm{ml}, 15 \mathrm{mmol})$. The mixture was stirred at $0^{\circ} \mathrm{C}$ for $5 \mathrm{~min}$, and a solution of sodium nitrite $(0.290 \mathrm{~g}, 4.2 \mathrm{mmol})$ in water $(1 \mathrm{ml})$ was added drop-wise so as to keep the reaction temperature below $5^{\circ} \mathrm{C}$. The mixture was stirred at $0-5^{\circ} \mathrm{C}$ for $15 \mathrm{~min}$, and then methyl acrylate $(2 \mathrm{ml}, 23 \mathrm{mmol})$ was added drop-wise. The mixture was warmed to $38^{\circ} \mathrm{C}$, powdered cuprous oxide $(120 \mathrm{mg}, 0.84 \mathrm{mmol}$ ) was added, and the mixture was stirred for $2 \mathrm{~h}$ at the same temperature, then made basic with concentrated aqueous ammonia, and extracted with EtOAc $(3 \times 20 \mathrm{ml})$. The combined extracts were washed with water and brine, dried over anhydrous $\mathrm{Na}_{2} \mathrm{SO}_{4}$, and concentrated. The title compound (3a) was isolated by column chromatography $\mathrm{MeOH} / \mathrm{DCM}(1: 10)$ as a pale brown solid (0.235 g, 15\%): $\mathrm{mp} 83-85^{\circ} \mathrm{C}$; FTIR (KBr): 2926, 2855 , 1734, 1600, 1486, 1406, 1364, 1239, 1016, 817, 750, $503 \mathrm{~cm}^{-1} ;{ }^{1} \mathrm{H}$ NMR $\left(\mathrm{CDCl}_{3}\right) \delta: 7.80-7.78(\mathrm{~m}, 2 \mathrm{H})$, 7.40-7.27 (m, 3H), 7.15-7.13 (d, J $=8.68 \mathrm{~Hz}, 2 \mathrm{H})$, $7.04-7.01(\mathrm{~d}, \mathrm{~J}=8.68 \mathrm{~Hz}, 2 \mathrm{H}), 5.37$ (s, 2H), 4.34 (dd, $\mathrm{J}=6.96 \mathrm{~Hz}, 1 \mathrm{H}), 3.89(\mathrm{~s}, 3 \mathrm{H}), 3.72(\mathrm{~s}, 3 \mathrm{H}), 3.40(\mathrm{dd}$, $\mathrm{J}=6.9 \mathrm{~Hz}, 1 \mathrm{H}), 3.18(\mathrm{dd}, \mathrm{J}=6.9 \mathrm{~Hz}, 1 \mathrm{H}) ; \mathrm{GCMS}$ $\mathrm{m} / \mathrm{z}(\%): 402(3.8)[\mathrm{M}]^{+}, 404(4)[\mathrm{M}+2]^{+}$and $145(100)$; Anal. Calcd for $\mathrm{C}_{19} \mathrm{H}_{19} \mathrm{BrN}_{2} \mathrm{O}_{3}: \mathrm{C}, 56.69 ; \mathrm{H}, 4.75 ; \mathrm{N}$, 6.95. Found: C, 56.85; H, 4.57; N, 6.73.

\subsection{General procedure for the synthesis of heterocyclyl linked benzylidene-1,3- thiazolidine-2,4-diones $\mathbf{4 a}$ and $8 \boldsymbol{a}$}

A mixture of (4/8) $(0.25 \mathrm{mmol})$, thiazolidine-2,4dione $(0.25 \mathrm{mmol})$ and catalytic quantity of piperidinium acetate in toluene $(50 \mathrm{ml})$ was refluxed for $7 \mathrm{~h}$ with continuous removal of water using a DeanStark water separator. The reaction mixture was cooled to $\mathrm{rt}$ and then stored inside a refrigerator overnight. The yellow precipitate was collected by filtration under suction, washed with hexane, and dried to obtain (4a/8a) as pale yellow solid.

2.6a 5-\{4-[(1-Methyl-1H-benzimidazol-2-yl)methoxy]benzylidene)-1,3-thiazolidine-2,4-dione (4a, scheme 1): Yield: $40 \%$, mp $271-273^{\circ} \mathrm{C}$; FTIR (KBr): 3410,2948 , 2850, 2532, 1730, 1704, 1580, 1509, 1482, 1450, 1408, 1334,1286, 1253, 1176, 1009, 831, $740 \mathrm{~cm}^{-1} ;{ }^{1} \mathrm{H}$ NMR $\left(\mathrm{DMSO}_{\mathrm{d}}\right) \delta: 7.75-7.73 ; 7.74(\mathrm{~d}, 1 \mathrm{H}), 7.68(\mathrm{~s}, 1 \mathrm{H})$,
7.47-7.41 (m, 3H), 7.36-7.29 (m, 2H), 7.21-7.19;7.20 $(\mathrm{d}, \mathrm{J}=8.80 \mathrm{~Hz}, 2 \mathrm{H}), 5.46$ (s, 2H), 3.91 (s, 3H); LCMS $\mathrm{m} / \mathrm{z}(366)[\mathrm{M}+1]^{+}$; Anal. Calcd for $\mathrm{C}_{19} \mathrm{H}_{15} \mathrm{~N}_{3} \mathrm{O}_{3} \mathrm{~S}: \mathrm{C}$, 62.45; H, 4.14; N, 11.50; S, 8.78. Found: C, 62.79; H, 4.135; N, 11.34; S.8.951.

2.6b Synthesis of 5-\{4-[(1-methyl-1H-indol-2-yl)methoxy]benzylidene $)$-1,3-thiazolidine-2,4-dione (8a, scheme 2): Yield: $32.0 \%$, mp: $173-175^{\circ} \mathrm{C}$; FTIR (KBr): 3402, 2926, 2850, 2588, 1732, 1701, 1595, $1508,1482,1334,1289,1250,1157,1013,820$, $735 \mathrm{~cm}^{-1} ;{ }^{1} \mathrm{H}$ NMR (DMSO-d 6 ) $\delta: 7.61(\mathrm{~d}, 1 \mathrm{H}), 7.48$ $(\mathrm{d}, \mathrm{J}=8.60 \mathrm{~Hz}, 2 \mathrm{H}), 7.35(\mathrm{~d}, 1 \mathrm{H}), 7.22(\mathrm{~m}, 1 \mathrm{H}), 7.11$ $(\mathrm{d}, \mathrm{J}=8.60 \mathrm{~Hz}, 3 \mathrm{H}), 7.07(\mathrm{~d}, 1 \mathrm{H}), 6.61(\mathrm{~s}, 1 \mathrm{H}), 5.28$ (s, 2H), 3.81 (s, 3H); LCMS m/z (365) $[\mathrm{M}+1]^{+}$; Anal. Calcd for $\mathrm{C}_{20} \mathrm{H}_{16} \mathrm{~N}_{2} \mathrm{O}_{3} \mathrm{~S}$ : C, 65.92; H, 4.43; N, 7.69; S, 8.80. Found: C, 65.72; H, 4.78; N, 7.75; S, 8.63.

\subsection{General procedure for the synthesis} of heterocyclyl linked diethyl benzylidene propanedioates $\mathbf{4 b}$ and $8 \boldsymbol{b}$

A solution of $(4 / 8)(2.8 \mathrm{mmol})$ and diethyl malonate $(5.1 \mathrm{mmol})$ in toluene $(30 \mathrm{ml})$ containing a catalytic quantity of piperidinium acetate was refluxed for $7 \mathrm{~h}$. After cooling to $\mathrm{rt}$, the solution was concentrated. The residue was chromatographed using a mixture of $\mathrm{MeOH}$ and DCM (1:99) or EtOAc and hexane (1:10) to give $(\mathbf{4 b} / \mathbf{8 b})$ as white solid.

2.7a Diethyl \{4-[(1-methyl-1H-benzimidazol-2-yl)methoxy]benzylidene\} propanedioate $(4 \mathrm{~b}$, scheme 1$)$ : Yield: $45 \%$, mp: $128-130^{\circ} \mathrm{C}$; FTIR (KBr): 2978,2934 , 2850, 1723, 1600, 1514,1471, 1399, 1260, 1212, 1175, $1064,1013,839,744 \mathrm{~cm}^{-1} ;{ }^{1} \mathrm{H}$ NMR $\left(\mathrm{CDCl}_{3}\right) \delta: 7.79$ $7.77(\mathrm{~m}, 1 \mathrm{H}), 7.64(\mathrm{~s}, 1 \mathrm{H}), 7.42-7.40(\mathrm{~d}, \mathrm{~J}=8.80 \mathrm{~Hz}$, 2H), 7.37-7.27 (m, 3H), $5.42(\mathrm{~s}, 2 \mathrm{H}), 7.09$ (d, J = $8.8,2 \mathrm{H}$ ), 4.30 (two overlapping quartet, $\mathrm{J}=7.2 \mathrm{~Hz}$, $4 \mathrm{H}), 3.88(\mathrm{~s}, 3 \mathrm{H}), 1.31(\mathrm{t}, \mathrm{J}=7.1 \mathrm{~Hz}, 3 \mathrm{H}), 1.29(\mathrm{t}, \mathrm{J}=$ $7.7 \mathrm{~Hz}, 3 \mathrm{H})$; LCMS m/z (409) $[\mathrm{M}+1]^{+}$; Anal. Calcd for $\mathrm{C}_{23} \mathrm{H}_{24} \mathrm{~N}_{2} \mathrm{O}_{5}$ : C, 67.63; H, 5.92; N, 6.86. Found: $\mathrm{C}$, $67.82 ; \mathrm{H}, 6.21 ; \mathrm{N}, 6.61$.

2.7b Diethyl \{4-[(1-methyl-1H-indol-2-yl)methoxy]benzylidene\} propanedioate $(8 \boldsymbol{b}$, scheme 2): Yield: 20.00\%, mp: $108-110^{\circ} \mathrm{C}$; FTIR (KBr): 2979, 2920, 2850, 1720, 1602, 1511, 1464, 1381, 1340, 1263, 1207, $1178,1007,833,751 \mathrm{~cm}^{-1} ;{ }^{1} \mathrm{H}$ NMR $\left(\mathrm{CDCl}_{3}\right) \delta: 7.67$ $(\mathrm{s}, 1 \mathrm{H}), 7.61(\mathrm{~d}, 1 \mathrm{H}), 7.44(\mathrm{~d}, \mathrm{~J}=8.8 \mathrm{~Hz}, 2 \mathrm{H}), 7.34(\mathrm{~d}$, $1 \mathrm{H}), 7.25(\mathrm{~m}, 1 \mathrm{H}), 7.12(\mathrm{~m}, 1 \mathrm{H}), 7.01(\mathrm{~d}, \mathrm{~J}=8.8 \mathrm{~Hz}$, $2 \mathrm{H}), 6.61(\mathrm{~s}, 1 \mathrm{H}), 5.22(\mathrm{~s}, 2 \mathrm{H}), 4.35(\mathrm{q}, \mathrm{J}=7.1 \mathrm{~Hz}$, 
2H), $4.29(\mathrm{q}, \mathrm{J}=7.1 \mathrm{~Hz}, 2 \mathrm{H}), 3.79(\mathrm{~s}, 3 \mathrm{H}), 1.33(\mathrm{t}$, $\mathrm{J}=4.3 \mathrm{~Hz}, 3 \mathrm{H}), 1.31(\mathrm{t}, \mathrm{J}=4.4 \mathrm{~Hz}, 3 \mathrm{H}) ; \mathrm{LCMS} \mathrm{m} / \mathrm{z}$ (407) $[\mathrm{M}+1]^{+}$; Anal. Calcd for $\mathrm{C}_{24} \mathrm{H}_{25} \mathrm{NO}_{5}$ : C, 70.46; H, 6.18; N, 3.44. Found: C, 70.13; H, 5.89; N, 3.27.

\subsection{Synthesis of diethyl 4 -[(1-methyl-1H- benzimidazol-2-yl)methoxy]benzyl\} propanedioate (compound $4 \boldsymbol{c}$, scheme 1)}

A solution of $\mathbf{4 b}(400 \mathrm{mg}, 0.98 \mathrm{mmol})$ in a mixture of methanol and dioxane (125:50) was shaken in the presence of $10 \% \mathrm{Pd}-\mathrm{C}(100 \mathrm{mg})$ in a Parr Hydrogenator under $20 \mathrm{psi}_{2}$ pressure at $\mathrm{rt}$ for $12 \mathrm{~h}$. The mixture was filtered through celite, and the filtrate was evaporated under reduced pressure. The residue upon recrystallization from methanol gave $\mathbf{4 c}(100 \mathrm{mg}, 25 \%)$ as an off white solid: $\mathrm{mp} 135-136^{\circ} \mathrm{C}$; FTIR (KBr): 2978,2935 , 2850, 1733,1610, 1511, 1475, 1372, 1235, 1147, 1037, $1013,825,744 \mathrm{~cm}^{-1} ;{ }^{1} \mathrm{H}$ NMR $\left(\mathrm{CDCl}_{3}\right) \delta: 7.78-7.76$ (m, 1H), 7.36-7.27 (m, 3H), 6.99-6.97 (m, 2H), 5.35 (s, 2H), 4.14 (two superimposed quartet, $\mathrm{J}=2.7 \mathrm{~Hz}$, $4 \mathrm{H}), 3.87(\mathrm{~s}, 3 \mathrm{H}), 3.57(\mathrm{t}, \mathrm{J}=7.8 \mathrm{~Hz}, 1 \mathrm{H}), 3.14(\mathrm{~d}$, $\mathrm{J}=7.8 \mathrm{~Hz}, 2 \mathrm{H}$ ), 1.18 (two superimposed triplet, $\mathrm{J}=$ $14.3 \mathrm{~Hz}, 6 \mathrm{H}) ; \mathrm{LCMS} \mathrm{m} / \mathrm{z}(411)[\mathrm{M}+1]^{+}$; Anal. Calcd for $\mathrm{C}_{23} \mathrm{H}_{26} \mathrm{~N}_{2} \mathrm{O}_{5}$ : C, 67.30; H, 6.38; N, 6.82. Found: $\mathrm{C}$, 67.47; H, 6.26; N, 6.59.

\section{Results and discussion}

The benzimidazolyl linked aldehyde and amino compounds were prepared by the synthetic route as shown in (scheme 1). $N$-methyl-1,2-phenylene diamine dihydrochloride (1) was cyclised drastically with glycolic acid and chloroacetic acid to furnish the corresponding hydroxyl-(1a) and chloro-(1b) compounds, respectively in excellent yields. These were reacted with 4-fluorobenzaldehyde ${ }^{25}$ and 4-hydroxobenzaldehyde to afford the aldehyde (4). The latter was condensed with diethyl malonate ${ }^{18}$ and 2,4-thiazolidinedione ${ }^{16}$ to give the benzylidenes (4b) and (4a), respectively. Catalytic hydrogenation of (4b) with $10 \%$ palladium on carbon gave $(\mathbf{4 c})$. The amine $(3)$ was prepared by treating (1a) with 4-chloronitrobenzene and subsequent catalytic reduction of the resulting nitro compound (2). The $\alpha$-bromoester (3a) was prepared from (3) by a known method. ${ }^{19}$

Scheme 2 shows the preparation of indolyl linked aldehyde and nitro compounds. The alcohol (5b) was prepared by a standard sequence from the ester (5) via $N$-methylation and subsequent reduction. The aldehyde (8) and nitro compound (6) were prepared from (5b) in a similar way as depicted in scheme 1 , the amine (7) was similarly obtained by reduction of (6). The benzylidenes $(\mathbf{8 b})$ and $(\mathbf{8 a})$ were obtained from (8) by condensation with diethyl malonate and 2,4thiazolidinediones, respectively.

Acridonyl linked aldehyde and nitro compounds were synthesized according to scheme 3 . Acridone ${ }^{26}$ (9) brormopropoxybenzaldehyde ${ }^{20}(\mathbf{9 b})$, and brormopropoxynitrobenzene ${ }^{20}$ (9a) were prepared by known procedures. The aldehydes (12) and the nitro compound (10) were prepared by microwave irradiation of (9) and the corresponding bromo propoxy compounds ${ }^{27}$ (9b and 9a), (10a) was subsequently reduced to obtain corresponding amine (11).

\section{Conclusion}

We report here the syntheses of benzaldehydes and anilines linked at the para position, with an alkoxy ether linkage to three crucial heterocycles namely, benzimidazole, indole and acridone. Representative procedure for the preparation of 1,3-diester, 2,4thiazolidinedione and $\alpha$-bromopropanoic acid ester derivatives in case of benzimidazole, and 1,3-diester and 2,4-thiazolidinedione derivative in case of indolebased precursors has been optimized, and the said compounds have been successfully synthesised and characterised.

\section{Acknowledgements}

Authors acknowledge the financial support from IndSwift Labs. Ltd. (ISLL), SAS Nagar, Mohali for the ISLL-Punjabi University Collaborative Research, and providing the research fellowship to two of the authors VK and PG.

\section{References}

1. (a) Porcari A R, Devivar R V, Kucera L S, Drach J C and Townsend L B 1998 J. Med. Chem. 411252 (b) Migawa M T, Girardet J, Walker II J A, Koszalka G W, Chamberlain S D, Drach J C and Townsend L B 1998 J. Med. Chem. 411242

2. Hasegawa $M$, Nishigaki $N$, Washio $Y$, Kano $K$, Harris PA, Hideyuki S, Ichiro Mori, West R I, Megumi S, Hiroko T, Wang L, Nolte R T, Veal J M and Cheung M 2007 J. Med. Chem. 504453

3. Alagöz Z A, Kuş C and Çoban T 2005 J. Enz. Inhib. Med. Chem. 22325

4. Mederski W K R, Dorsch D, Anzali S, Gleitz J, Cezanne B and Tsaklakidis C 2004 Bioorg. Med. Chem. Lett. 14 3763

5. Kubo K, Kohara Y, Yoshimura Y, Inada Y, Shibouta Y, Furukawa Y, Kato T, Nishikawa K and Naka T 1993 J. Med. Chem. 362343 
6. Vázquez G N, Yépezb L, Camposa A H, Tapiab A, Luisa F H, Cedilloc R, Gonzáleza J, Fernándezd A M, Grueirod M M and Castillo R 2003 Bioorg. Med. Chem. 114615

7. (a) Aggarwal B B and Ichikawa 2005 Cell Cycle 41201 (b) Safe S, Papineni S and Chintharlapalli S 2008 Cancer Lett. 26926 (c) Weng J R, Tsai C H, Kulp S K, Wang D, Lin C H, Yang H C, Ma Y, Sargeant A, Chiu C F, Tsai M H and Chen C S 2007 Cancer Res. 677815

8. (a) Huffmana J W, Zengina G, Wua M J, Lua J, Hynda G, Bushella K, Thompsona A L S, Bushella S, Tartalb C, Hurstb D P, Reggiob P H, Selleyc D E, Cassidyc M P, Wileyc J L and Martinc B R 2005 Bioorg. Med. Chem. 1389 (b) Jennifer M, Frost J M, Dart M J, Tietje K R, Garrison T R, Grayson G K, Daza A V, El-Kouhen O F, Yao B B, Hsieh G C, Pai M, Zhu C Z, Chandran P and Meyer M D $2010 \mathrm{~J}$. Med. Chem. 53295

9. Andreani A, Burnelli S, Granaiola M, Leoni A, Locatelli A, Morigi R, Rambaldi M, Varoli L, Landi L, Prata C, Berridge M V, Grasso C, Fiebig H H, Kelter G, Burger A M and Kunkel M W 2008 J. Med. Chem. 514563

10. Sugiyama Y, Ito Y, Suzuki M and Hirota A 2009 J. Nat. Prod. 722069

11. Bi W, Bi Y, Xue P, Zhang Y, Gao X, Wang Z, Li M, Ngerebara M B N, Gibson K M and Bi L 2010 J. Med. Chem. $\mathbf{5 3} 6763$

12. Bastow K F and Lowden C T Patent US 2005/0049273 Al.

13. Nguyen H, Lallemand M C, Boutefnouchet S, Michel S and Tillequin F 2009 J. Nat. Prod. 72527

14. (a) Manfroni G, Paeshuyse J, Massari S, Zanoli S, Gatto B, Maga G, Tabarrini O, Cecchetti V, Fravolini A and Neyts J 2009 J. Med. Chem. 523354 (b) Drogo A S, Drner B, Erker T and Chachulska A M B 2010 J. Med. Chem. $\mathbf{5 3} 3117$
15. Riscoe M K Patent WO 2008/06401

16. Neogi P, Lakner F J, Edicherla S, Heng J, Dey D, Gowri M, Nag B, Sharma S D, Pickford L B and Gross C 2003 Bioorg. Med. Chem. 114059

17. Momose $\mathrm{Y}$, Maekawa T, Yamano T, Kawada M, Odaka H, Ikeda H and Sohda T 2002 J. Med. Chem. 45 1518

18. Shinkai H, Onogi S, Tanaka M, Shibata T, Iwao M, Wakitani K and Uchida I 1998 J. Med. Chem. 411927

19. Hulin B, Newton L S, Lewis M D, Genereux P E, Gibbs E M and Clark D A 1996 J. Med. Chem. 393897

20. Cai Z, Feng J, Guo Y, Li P, Shen Z, Chu F and Guo Z 2006 Bioorg. Med. Chem. 14866

21. Reddy K A, Lohray B B, Bhushan V, Reddy A S, Mamidi N V S, Reddy P P, Saibaba V, Reddy N J, Suryaprakash A, Misra P, Vikramadithyan R K and Rajagopalan R 1999 J. Med. Chem. 423265

22. Lohray B B, Bhushan V, Reddy A S, Rao P B, Reddy N J, Harikishore P, Haritha N, Vikramadityan R K, Chakrabarti R, Rajagopalan R and Katneni K 1999 J. Med. Chem. 422569

23. Ramlaa M M, Omara M A, Tokudab H and El-Diwania H I 2007 Bioorg. Med. Chem. 156489

24. Henke B R, Blanchard S G, Brackeen M F, Brown K K, Cobb J E, Collins J, Harrington W W, Lehmann J M, Lenhard J M, Plunket K D, Szewczyk D and Willson T M 1998 J. Med. Chem. 415020

25. Cantello B C C, Cawthorne M A, Cottam G P, Duff P T, Haigh D, Hindley R M, Lister C A, Smith S A and Thurlby P L 1994 J. Med. Chem. 373977

26. Allen C F H and McKee G H W 1943 Organic Syntheses, Coll. 2(15)

27. Fan X, You J, Jiao T, Tan G and Yu X 2009 Org. Prep. Proc. Int. 32284 